\title{
Pengaruh Blansing dan Perendaman Asam Sitrat Terhadap Mutu Fisik dan Kandungan Gizi Tepung Buah Pandan Tikar (Pandanus tectorius Park.)
}

\section{Effect of blanching and immersion of citric acid on physical quality and nutritional content of Pandan Tikar (Pandanus tectorius Park.) flour}

\author{
Sritina N. P. Paiki ${ }^{1}, \operatorname{Irman}^{1}$, Zita Letviany Sarungallo ${ }^{1 *}$, Rossa Martha Marlen Latumahina ${ }^{1}$, \\ Cicilia Maria Erna Susanti ${ }^{2}$, Nurhaidah Iriyani Sinaga ${ }^{3}$, Diana Nurini Irbayanti ${ }^{4}$ \\ ${ }^{1}$ Lab. Teknologi Pertanian, Fakultas Teknologi Pertanian, Universitas Papua. Jl. Gunung Salju, Amban, \\ Manokwari-98314, Papua Barat \\ ${ }^{2}$ Lab. Teknologi Hasil Hutan, Fakultas Kehutanan, Universitas Papua. Jl. Gunung Salju, Amban, Manokwari- \\ 98314, Papua Barat \\ ${ }^{3}$ Lab. Konservasi Sumber Daya Hutan dan Lingkungan, Fakultas Kehutanan, Universitas Papua. Jl. Gunung \\ Salju, Amban, Manokwari-98314, Papua Barat \\ ${ }^{4}$ Lab. Agribisnis, Fakultas Pertanian, Universitas Papua. J1. Gunung Salju, Amban, Manokwari-98314, Papua \\ Barat \\ *Email: zlsarungallo@yahoo.com
}

\begin{abstract}
The problem in making pandan tikar flour (Pandanus tectorius Park.) is an enzymatic browning reaction during the incision and drying process, due to contact with oxygen. This study aims to determine the effect of blanching and immersion of citric acid on the physical quality and nutritional composition of the pandan tikar flour produced. Preventive treatment of browning reactions in pandan tikar flour includes blanching (steamed at $80^{\circ} \mathrm{C}$, for 3 minutes), soaking with a citric acid solution $(2 \%, w / v)$ and compared with control (without treatment). The results of this study showed that the blanching treatment in pandan tikar fruit can prevent the browning enzymatic reaction that is more effective than soaking with a citric acid solution in the resulting flour; with physical characteristics of the yield value (16.21\%), brightness level - L value (76.29), redness level - a value (2.41), yellowish level - $b$ value (25.82), temperature gelatinization $\left(92.33{ }^{\circ} \mathrm{C}\right)$, water solubility $(53.43 \%)$; and water content $(10.08 \%, w b)$, ash $(10.00 \%, d b)$, protein $(5.73 \%, d b)$, fat $(2.24 \%, d b)$, and carbohydrate $(82.03 \%, d b)$, crude fiber $(24.42 \%, d b)$ and total sugar $(26.00 \%, d b)$.
\end{abstract}

Key words: Pandanus tectorius Park, flour, fruit, physical quality and nutritional content.

\begin{abstract}
Abstrak
Kendala utama dalam pembuatan tepung buah pandan tikar (Pandanus tectorius Park.) adalah reaksi pencoklatan enzimatis selama proses pengirisan dan pengeringan, akibat adanya kontak dengan oksigen. Keadaan ini dapat dikurangi dengan perlakuan fisik dan kimiawi. Penelitian ini bertujuan untuk menentukan pengaruh blansing dan perendaman asam sitrat terhadap mutu fisik dan komposisi gizi tepung buah pandan tikar. Perlakukan yang digunakan dalam penelitian ini adalah blansing (dikukus pada $80^{\circ} \mathrm{C}, 3$ menit), dan perendaman dalam asam sitrat $(2 \%, \mathrm{~b} / \mathrm{v})$. Hasil penelitian ini menunjukkan bahwa perlakuan blansing dapat mencegah terjadinya reaksi pencoklatan enzimatis dibandingkan perendaman dengan daging buah asam sitrat pada tepung pandan tikar yang dihasilkan; dengan nilai rendemen $(16,21 \%)$, tingkat kecerahan - nilai L $(76,29)$, tingkat kemerahan - nilai a $(2,41)$, tingkat kekuningan - nilai $\mathrm{b}(25,82)$, suhu gelatinisasi $\left(92,33{ }^{\circ} \mathrm{C}\right)$, kelarutan dalam air $(53,43 \%)$; serta mengandung air $(10,08 \% \mathrm{bb})$, abu $(10,00 \% \mathrm{bk})$, protein $(5,73 \% \mathrm{bk})$, lemak $(2,24 \% \mathrm{bk})$, karbohidrat $(82,03 \%$ bk), serat kasar $(24,42 \%$ bk) dan total gula $(26,00 \%$ bk).
\end{abstract}

Kata kunci: Pandanus tectorius Park., tepung, buah, mutu fisik dan kandungan gizi. 


\section{PENDAHULUAN}

Pandan tikar (Pandanus tectorius Park.) termasuk golongan tumbuhan monokotil dari famili Pandanaceae, yang tumbuh di sepanjang garis pantai. Pohon dari tanaman pandan berumpun dan bercabang lebar dengan ketinggian pohon sekitar 3-5 m, memiliki daun tersusun spiral dengan ujung daun meruncing dan panjang daunnya sekitar 2-2.6 m, memiliki akar tunjang yang tingginya sekitar 1-2.5 m dan berada hampir setengah dari tinggi pohon (Raunsai dan Elewyaan, 2018). Pandan mempunyai jenis buah majemuk (cephalium), dengan bentuk buah bervariasi mulai dari bulat telur, menjorong (ellipsoid), agak bulat, dan serupa bola (Antares $d k k$., 2017).

Pandan tikar banyak tumbuh di sepanjang garis pantai Pulau Mansinam, namun belum dimanfaatkan sebagai bahan pangan oleh masyarakat lokal. Sementara Sarungallo $d k k$. (2018) melaporkan bahwa kandungan gizi buah pandan tikar pada tingkat kematangan agak matang yang berasal dari Pulau Mansinam cukup tinggi meliputi kadar air $(74,21 \%)$, protein $(4,30 \%)$, lemak $(0,36 \%)$, abu $(5,45 \%)$, karbohidrat $(89,88 \%)$, serat kasar $(25,95 \%)$, total gula $(31,60 \%)$, serta $\beta$-karoten (26,49 ppm). Dengan demikian, buah pandan tikar berpotensi untuk diolah menjadi berbagai produk pangan, salah satunya adalah pembuatan tepung buah pandan tikar.

Kendala yang dihadapi dalam pembuatan tepung buah pandan tikar adalah terjadinya reaksi pencoklatan enzimatis selama proses pengirisan dan pengeringan, akibat adanya kontak dengan oksigen. Reaksi pencoklatan yang terjadi dapat menyebabkan perubahan pada sifat tepung yang dihasilkan terutama warna tepungnya, sehingga perlu dilakukan penghambatan. Penghambatan reaksi pencoklatan dapat dilakukan dengan cara blansing dan perendaman asam sitrat.

Blansing merupakan proses pemanasan cepat untuk menginaktifkan enzim yang dilakukan pada suhu di bawah $100^{\circ} \mathrm{C}$ selama beberapa menit, dengan menggunakan air panas dan/atau uap panas (Efendi $d k k$., 2015). Adanya perlakuan panas dapat mengakibatkan penurunan aktifitas enzim karena mengalami denaturasi (Mardiah, 2011). Sedangkan asam sitrat merupakan senyawa asam organik yang mampu mengkompleks ion tembaga yang berperan sebagai katalis dalam reaksi pencoklatan (browning) enzimatis. Selain itu juga asam sitrat dapat menghambat browning enzimatis dengan cara menurunkan $\mathrm{pH}$ sehingga enzim polifenol oksidase menjadi inaktif (Winarno, 2008). Inggrid $d k k$. (2018) melaporkan bahwa penambahan asam sitrat sebanyak $1.5 \%$ (w/v) pada hancuran kentang dapat menghambat terjadinya reaksi browning sebesar $76.75 \%$. Dijelaskan pula bahwa penambahan asam sitrat sebagai zat antibrowning berfungsi menurunkan $\mathrm{pH}$ hingga 2.63 dan sebagai chelating agent. Penurunan kadar asam hingga lebih rendah dari $\mathrm{pH}$ optimum enzim dapat menyebabkan enzim mengalami denaturasi, enzim menjadi tidak aktif sehingga reaksi browning tidak terbentuk. Oleh karena itu, pada penelitian ini dilakukan proses penghambatan reaksi pencoklatan pada tepung pandan tikar dengan mengunakan cara blansing dan perendaman asam sitrat. Penelitian ini bertujuan untuk menentukan pengaruh blansing dan perendaman dengan asam sitrat terhadap mutu fisik dan komposisi gizi tepung buah pandan tikar yang dihasilkan.

\section{METODOLOGI}

\section{Bahan dan alat}

Bahan baku utama yang digunakan membuat tepung adalah buah pandan tikar yang diperoleh dari Pulau Mansinam, Kabupaten Manokwari, dengan tingkat kematangannya adalah agak matang. Buah pandan tikar dengan tingkat kematangan agak matang memiliki ciri warna bagian yang dapat dimakan adalah kuning muda serta jarak antar drupa rapat dan keras saat dilepaskan dari empulur (Sarungallo $d k k$., 2018). Bahan pendukung lainnya adalah asam sitrat (2\%), aquades, $\mathrm{HCl}, \mathrm{NHCl}, \mathrm{NaOH}, \mathrm{K}_{2} \mathrm{SO}_{4}, \mathrm{H}_{2} \mathrm{SO}_{4}$, $\mathrm{HgO}$, heksan, toluene dan etanol.

Alat yang digunakan pada penelitian ini adalah dandang, pisau, sendok, loyang, kompor, kertas label, blender, dan ayakan (80 mesh), labu ukur, sudip, timbangan analitik, oven, cawan, hot plate, vortex, labu lemak, alat destilasi, buret, soxhlet, tanur pengabuan, labu kjeldhal, termometer, dan kertas saring.

\section{Metode Penelitian}

\section{Pembuatan Tepung Buah Pandan Tikar}

Tahapan pembuatan tepung buah pandan tikar adalah sortasi, pencucian, pengirisan, pengeringan, penghancuran, pengayakan, dan pengemasan. Untuk perlakuan blansing, hasil irisan dikukus $\left(80^{\circ} \mathrm{C}\right)$ selama 5 menit terlebih 
dahulu sebelum dikeringkan dan ditepungkan. Sementara untuk perlakuan perendaman asam sitrat, hasil irisan direndam di dalam larutan asam sitrat $(2 \%, \mathrm{~b} / \mathrm{v})$ selama 30 menit lalu dikeringkan dan ditepungkan. Proses pengeringan dilakukan dengan menggunakan oven (suhu $60{ }^{\circ} \mathrm{C}$ ) selama \pm 3 jam (ditandai dengan irisan yang dikeringkan mudah dipatahkan). Setelah kering, irisan dihaluskan dan diayak menggunakan ayakan 80 mesh dan dikemas.

Sifat Fisik dan Proksimat Tepung Buah Pandan Tikar

Tepung buah pandan tikar yang dihasilkan dianalisis sifat fisik yang meliputi rendemen, warna (chromameter), aroma, suhu gelatinisasi (Sudarmadji dkk., 1997) dan kelarutan dalam air (Sathe dan Salunkhe, 1981). Serta komposisi gizi yang dianalisis meliputi kadar air (metode oven), kadar lemak (ekstraksi soxhlet), kadar protein (kjeldahl mikro), kadar abu (metode tanur) (AOAC, 2005), sedangkan karbohidrat ditentukan berdasarkan by different, serta kadar serat kasar (metode gravimetri), dan total gula (metode Anthrone, Apriyantono dkk., 1989).

\section{Analisis data}

Data karakteristik fisik buah yang diperoleh dari penelitian ini dianalisis secara deskriptif yang disajikan dalam bentuk tabel dan gambar. Sedangkan data karakteristik fisik dan kandungan gizi tepung dianalisis menggunakan analisis sidik ragam (Analysis of Varians) dan jika terdapat perbedaan nyata maka dilakukan uji lanjut menggunakan DMRT (Duncans Multiple Range Test) dengan program SPSS (Statistical Productand Service Solution), versi 17,0.

\section{HASIL DAN PEMBAHASAN}

\section{Karakteristik Fisik Buah Pandan Tikar (P. tectorius Park.)}

Buah pandan tikar yang digunakan memiliki tingkat kematangan agak matang. Hal ini karena semakin matang buah pandan tikar, maka semakin tinggi kandungan total gulanya. Kadar gula yang tinggi dapat menyebabkan terjadinya karamelisasi pada saat pemanasan sehingga dapat mempengaruhi warna tepung yang dihasilkan. Sarungallo $d k k$. (2018) melaporkan bahwa total gula pada buah pandan tikar agak matang adalah $31.6 \%$ (bk) dan mengalami peningkatan menjadi $44.8 \%$ (bk) pada buah matang. Karakteristik fisik buah pandan tikar yang digunakan sebagai bahan baku pembuatan tepung tersaji pada Tabel 1.

Tabel 1. Karakteristik Fisik Buah Pandan Tikar

\begin{tabular}{lc}
\hline \multicolumn{1}{c}{ Sifat Fisik } & $\begin{array}{l}\text { Buah Pandan } \\
\text { Tikar }\end{array}$ \\
\hline Bentuk buah utuh & Bulat lonjong \\
Warna buah bagian yang & Kuning muda \\
dimakan & $1-2$ \\
Berat buah (kg) & $42-60$ \\
Jumlah drupa (drupa) & \pm 2 \\
Berat daging buah per drupa (g) & \\
\hline
\end{tabular}

Bentuk buahnya adalah bulat lonjong yang terdiri dari dua bagian yaitu drupa dan empulur. Drupa berwarna kuning pada bagian pangkalnya dan hijau pada bagian ujung yang terdiri dari dua bagian yaitu daging buah dan biji. Sementara empelur adalah bagian berwarna kuning muda yang terletak dibagian tengah buah dan merupakan tempat menempelnya drupa. Daging buah merupakan bagian berwarna kuning muda yang berada pada pangkal buah, dimana bagian ini merupakan bagian yang dapat dimakan. Sarungallo $d k k$. (2018) melaporkan bahwa warna daging buah agak matang adalah kuning muda dan memiliki jarak antar drupa yang rapat serta keras saat hendak dilepaskan dari empelur.

\section{Sifat Fisik Tepung Buah Pandan Tikar (P. tectorius Park.)}

Sifat fisik tepung buah pandan tikar dengan 3 perlakuan yaitu kontrol, blansing, dan perendaman asam sitrat disajikan pada Tabel 2. 
Tabel 2. Sifat Fisik Tepung Buah Pandan Tikar

\begin{tabular}{lccc}
\hline \multirow{2}{*}{ Parameter sifat fisik } & \multicolumn{3}{c}{ Perlakuan tepung } \\
\cline { 2 - 4 } & Kontrol & Blansing & Perendaman asam sitrat \\
\hline Rendemen (\%) & 16,34 & 16,21 & 15,71 \\
Warna (nilai Hunter) & & & \\
$\quad$ Nilai L & $71,03^{\mathrm{a}}$ & $76,29^{\mathrm{b}}$ & $77,82^{\mathrm{c}}$ \\
Nilai a & $3,94^{\mathrm{c}}$ & $2,41^{\mathrm{a}}$ & $2,71^{\mathrm{b}}$ \\
$\quad$ Nilai b & $19,36^{\mathrm{c}}$ & $25,82^{\mathrm{a}}$ & $20,94^{\mathrm{b}}$ \\
Aroma & Buah pandan & Buah pandan & Berbau agak asam \\
Suhu gelatinisasi $\left({ }^{\circ} \mathrm{C}\right)$ & $93,33^{\mathrm{b}}$ & $92,33^{\mathrm{a}}$ & $93^{\mathrm{ab}}$ \\
Kelarutan dalam air $(\%)$ & $51,53^{\text {ns }}$ & $53,43^{\text {ns }}$ & $48,56^{\mathrm{ns}}$ \\
\hline *Huruf yang berbeda dibelakang angka menunjukkan perbedaan nyata & \\
**Nilai tingkat kecerahan (L), tingkat kemerahan (a), dan tingkat kekuningan (b)
\end{tabular}

Hasil pengujian pada Tabel 2 menunjukkan bahwa rendemen tepung tertinggi adalah perlakuan kontrol (tanpa perlakuan) $16,34 \%$ dan terendah pada perlakuan asam sitrat $15,71 \%$. Rendahnya rendemen pada perlakuan asam sitrat diduga berkaitan dengan kerusakan dinding sel daging buah selama perendaman 30 menit. Kerusakan dinding sel tersebut dapat mempengaruhi permeabilitas sel bahan sehingga memudahkan penguapan air selama proses pengeringan.

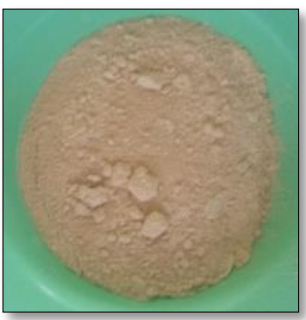

a

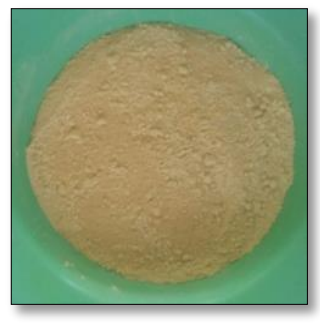

b

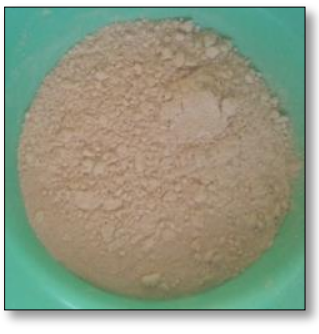

$\mathrm{c}$

Gambar 1. Tepung buah pandan tikar dengan 3 perlakuan; (a) kontrol, (b) blansing, (c) perendaman asam sitrat

Warna merupakan salah satu profil visual yang menjadi kesan pertama konsumen dalam menilai suatu mutu produk pangan. Warna tepung buah pandan tikar dicirikan oleh nilai L (tingkat kecerahan), nilai a (tingkat kemerahan), dan nilai b (tingkat kekuningan). Secara visual warna tepung yang dihasilkan dari perlakuan kontrol berwarna coklat, blansing berwarna kuning, dan perendaman asam sitrat agak coklat (Gambar 1).

Nilai L merupakan nilai yang menunjukkan tingkat kecerahan, dimana semakin besar nilai L maka warna sampel semakin cerah sebaliknya semakin kecil nilai L maka akan semakin gelap (Pardede $d k k$., 2017). Hasil uji lanjut dengan Duncan (Tabel 2) memperlihatkan bahwa nilai $L$ tepung buah padan tikar pada perlakuan perendaman asam sitrat paling tinggi berbeda nyata dengan perlakuan blansing dan kontrol. Hal ini diduga disebabkan karena selama perendaman asam sitrat, senyawa organik mampu mengkompleksion tembaga yang berperan sebagai katalis dalam reaksi pencoklatan. Selain itu, asam sitrat juga dapat menghambat pencoklatan dengan menurunkan $\mathrm{pH}$ sehingga enzim polifenol oksidase menjadi inaktif (Winarno, 2008). Dijelaskan pula oleh Mardiah (2011) bahwa pada pH rendah, enzim akan terprotonasi sehingga kehilangan mutan negatifnya yang menyebabkan terjadi penurunan aktifitas enzim.

Nilai a merupakan nilai yang menunjukkan tingkat kemerahan, dimana semakin besar nilai a maka warna akan semakin merah (gelap) sebaliknya semakin kecil nilai a maka warna semakin muda atau lebih terang (Pardede $d k k$., 2017). Hasil uji lanjut dengan Duncan pada Tabel 2 memperlihatkan bahwa nilai a tepung buah 
padan tikar pada perlakuan blansing paling rendah berbeda nyata dengan perlakuan kontrol dan asam sitrat.

Hal ini diduga karena pigmen antosianin pada bahan mengalami kerusakan akibat pengaruh suhu yang tinggi sehingga menjadi tidak berwarna yang menyebabkan penurunan tingkat kemerahan pada tepung. Oktavianti dan Putri (2015) melaporkan bahwa terjadi penurunan tingkat kemerahan warna tepung ubi jalar ungu pada perlakuan blansing karena pigmen antosianin pada bahan mengalami kerusakan akibat pengaruh suhu yang tinggi. Ditambahkan pula bahwa pigmen antosianin yang mengalami kerusakan menjadi tidak berwarna sehingga tingkat kemerahan pada tepung akan menurun.

Nilai b merupakan nilai yang menunjukkan tingkat kekuningan, semakin besar nilai $b$ maka warna sampel semakin kuning sedangkan semakin kecil nilai b maka warna kuning akan semakin berkurang (Pardede dkk., 2017). Tabel 2 menunjukkan bahwa nilai (b) tepung buah pandan tikar perlakuan blansing paling tinggi berbeda nyata dengan perlakuan kontrol dan perendaman asam sitrat. Hal ini diduga karena adanya pemanasan dapat menonaktifkan enzim polifenoloksidase sehingga mencegah reaksi pencoklatan enzimatis yang dapat menyebabkan perubahan warna. Menurut Estiasih dan Ahmadi (2009), dengan adanya perlakuan blansing maka enzim polifenoloksidase dalam bahan dapat dinonaktifkan sehingga perubahan warna akibat reaksi pencoklatan enzimatis dapat diminimalkan.

Aroma merupakan sensasi sensori yang dialami oleh indera pembau dimana dapat mempengaruhi penerimaan konsumen terhadap suatu produk makanan (Nuriani, 2011). Menurut Vahirua-Lecha $d k k$. (1996) buah pandan tikar mengandung senyawa-senyawa ester terutama Geranyl acetate, 3-Methyl-3buten-1-yl acetate. Senyawa-senyawa ester ini umumnya bersifat volatil dan diduga berkontribusi dalam memberikan aroma khas pada tepung buah pandan tikar yang dihasilkan. Pada Tabel 2 menunjukkan bahwa aroma tepung buah pandan tikar dengan perlakuan perendaman asam sitrat adalah agak asam. Hal ini karena asam sitrat termasuk dalam golongan asidulan yaitu senyawa kimia yang bersifat asam sehingga dapat berkontribusi dalam memberikan aroma asam pada tepung yang dihasilkan.

Hasil uji lanjut Duncan pada Tabel 2 menunjukkan bahwa suhu gelatinisasi tepung buah pandan tikar pada perlakuan blansing paling rendah berbeda nyata dengan kontrol, tetapi tidak berbeda nyata dengan perlakuan perendaman asam sitrat. Hal ini diduga karena selama blansing maupun perendaman dengan asam sitrat menyebabkan terjadi pembengkakan granula pati akibat adanya uap air panas selama blansing ataupun penyerapan air selama perendaman dalam asam sitrat.

Nilai kelarutan dalam air menunjukkan tingkat kemudahan suatu tepung untuk dapat larut dalam air. Semakin tinggi nilai suatu kelarutan bahan maka akan semakin tinggi pula kemudahan tepung untuk larut dalam air (Prabasini $d k k ., 2013$ ). Hasil analisis ragam pada Tabel 2 menunjukkan bahwa ketiga perlakuan memberikan pengaruh tidak nyata $(\mathrm{P}>0,05)$ terhadap kelarutan dalam air tepung buah pandan tikar. Ini disebabkan karena tepung buah panda tikar yang dihasilkan masih banyak mengandung serat tidak larut air. Pada Tabel 3 menunjukkan bahwa kadar serat tepung buah pandan kadar serat berkisar 24,42$28,03 \%$, dan blansing memiliki kadar serat paling rendah. Hal ini selaras dengan kelarutan air dalam tepung buah pandan tikar pada perlakuan blansing paling tinggi $(53,43 \%)$, diduga karena adanya pemanasan yang dapat merusak struktur gel pektin dan hemiselulosa. Hasil penelitian Suprapto (2004) menyatakan perlakuan blansing menyebabkan turunnya kadar serat kasar stik ubijalar, akibat adanya pemanasan yang dapat merusak struktur gel pektin dan hemiselulosa.

\section{Kandungan Gizi Tepung Buah Pandan Tikar (P. tectorius Park.)}

Kandungan gizi tepung buah pandan tikar yang dihasilkan dari tanpa perlakuan (kontrol), perlakuan blansing, dan perendaman asam sitrat disajikan pada Tabel 3 . 
Tabel 3. Kandungan Gizi Tepung Buah Pandan Tikar

\begin{tabular}{lccc}
\hline \multirow{2}{*}{ Kandungan gizi } & \multicolumn{3}{c}{ Perlakuan tepung buah pandan tikar } \\
\cline { 2 - 4 } & Kontrol & Blansing & Perendaman asam sitrat \\
\hline Kadar air $(\%$, bb) & $10,71^{\mathrm{c}}$ & $10,08^{\mathrm{b}}$ & $8,02^{\mathrm{a}}$ \\
Abu $(\%, \mathrm{bk})$ & $10,69^{\mathrm{c}}$ & $10,00^{\mathrm{b}}$ & $8,94^{\mathrm{a}}$ \\
Protein $(\%$, bk) & $5,74^{\mathrm{b}}$ & $5,73^{\mathrm{b}}$ & $5,31^{\mathrm{a}}$ \\
Lemak $(\%, \mathrm{bk})$ & $2,64^{\mathrm{c}}$ & $2,24^{\mathrm{a}}$ & $2,54^{\mathrm{b}}$ \\
Karbohidrat $(\%$, bk) & $80,93^{\mathrm{a}}$ & $82,03^{\mathrm{b}}$ & $83,21^{\mathrm{c}}$ \\
Serat kasar $(\%$, bk) & $24,83^{\mathrm{b}}$ & $24,42^{\mathrm{a}}$ & $28,03^{\mathrm{c}}$ \\
Total gula $(\%$, bk) & $25,00^{\mathrm{b}}$ & $26,00^{\mathrm{c}}$ & $24,00^{\mathrm{a}}$ \\
\hline
\end{tabular}

*Huruf yang berbeda dibelakang angka menunjukkan perbedaan nyata

Kadar air merupakan banyaknya air yang terkandung dalam bahan yang dinyatakan dalam persen (Winarno, 2008). Hasil uji lanjut Duncan pada Tabel 3 memperlihatkan bahwa kadar air tepung pandan tikar dengan perlakuan perendaman asam sitrat paling rendah berbeda nyata dengan kontrol dan perlakuan blansing. Hal ini selaras dengan hasil perhitungan rendemen pada Tabel 2 yaitu perlakuan asam sitrat memiliki rendemen tepung paling rendah $(15,71 \%)$ dibandingkan perlakuan blansing dan kontrol. Hal ini diduga karena berkaitan dengan kerusakan dinding sel daging buah akibat perendaman dalam asam sitrat selama 30 menit yang dapat mempengaruhi permeabilitas sel bahan sehingga memudahkan penguapan air selama proses pengeringan.

Data pada Tabel 3 menunjukkan bahwa tepung buah pandan tikat dengan perlakuan perendaman asam sitrat memiliki kadar abu paling rendah berbeda nyata dengan perlakuan blansing dan kontrol. Hal ini disebabkan karena mineral larut air ikut terlarut selama proses perendaman dalam asam sitrat.

Kadar protein tepung buah pandan tikar berada pada kisaran 5,31-5,74\% bk (Tabel 3). Hasil uji lanjut Duncan memperlihatkan bahwa kadar protein tepung buah padan tikar pada perlakuan asam sitrat paling rendah berbeda nyata dengan perlakuan blansing dan kontrol, tetapi perlakuan blansing dan kontrol tidak berbeda nyata. Hal ini diduga karena protein larut air ikut terlarut selama proses perendaman dengan asam sitrat.

Kadar lemak tepung buah pandan tikar berada pada kisaran 2,24-2,64\% bk (Tabel 3). Hasil uji Duncan $(\mathrm{P}<0,05)$ memperlihatkan bahwa kadar lemak tepung buah pandan tikar dengan perlakuan blansing paling rendah berbeda nyata dengan perlakuan kontrol dan perendaman asam sitrat. Kadar lemak lebih rendah pada perlakuan blansing akibat peran uap panas yang dapat mempercepat gerakangerakan molekul lemak menjadi besar dan akan mempermudah proses pengeluaran lemak (Winarno, 2008).

Kadar karbohidrat tepung buah pandan tikar kadar berkisar $80.93-83.21 \%$ bk (Tabel 3). Hasil uji Duncan $(\mathrm{P}<0,05)$ memperlihatkan bahwa kadar karbohidrat tepung buah pandan tikar perlakuan perendaman asam sitrat paling tinggi berbeda nyata dengan kontrol dan perlakuan blansing. Nilai kadar karbohidrat mengikuti/selaras dengan nilai kadar air dari ketiga perlakuan. Hal ini disebabkan karena penentuan kadar karbohidrat pada penelitian ini menggunakan metode by different yaitu penentuan kadar karbohidrat berdasarkan selisih persentase keseluruhan bahan dengan total penjumlahan kadar air, lemak, protein, dan kadar abu. Dengan demikian maka semakin tinggi kadar komponen gizi yang lain maka kadar karbohidrat bahan akan semakin rendah dan sebaliknya semakin rendah kadar komponen gizi maka kadar karbohidrat semakin tinggi (Kusumawati $d k k$., 2012).

Serat pangan adalah bagian tumbuhan yang dapat dimakan atau analog dengan karbohidrat, yang tahan terhadap pencernaan dan absorpsi di dalam usus halus manusia dan mengalami fermentasi sebagian atau seluruhnya di dalam usus besar, meliputi polisakarida, karbohidrat analog (pati resisten dan senyawa karbohidrat sintetis), oligosakarida, lignin dan bahan yang terkait dengan dinding sel tanaman (waxes, cutin, suberin) (AACC,1983). Kadar serat tepung buah pandan kadar serat berkisar 24,4228,03\% (Tabel 3). Hasil uji Duncan $(\mathrm{P}<0,05)$ memperlihatkan bahwa kadar serat tepung buah pandan tikar perlakuan blansing paling 
rendah berbeda nyata dengan perlakuan kontrol dan perendaman asam sitrat. Hal ini diduga karena selama blansing menyebabkan struktur dinding sel menjadi rusak sehingga menurunkan kadar serat kasar. Hasil penelitian Suprapto (2004) menyatakan perlakuan blansing menyebabkan turunnya kadar serat kasar stik ubijalar, akibat adanya pemanasan yang dapat merusak struktur gel pektin dan hemiselulosa.

Kadar total gula merupakan kandungan gula keseluruhan dalam suatu bahan pangan yang terdiri dari gula pereduksi dan non perduksi yang terdiri dari golongan monosakarida, disakarida, oligosakarida dan polisakarid (Apriyantono dkk., 1989). Kadar total gula tepung buah pandan tikar berkisar 24-26\% (bk) (Tabel 3). Hasil uji lanjut Duncan $(\mathrm{P}<0,05)$ menunjukkan bahwa kadar total gula tepung buah pandan tikar perlakuan blansing paling tinggi berbeda nyata dengan perlakuan asam sitrat dan kontrol. Adanya air dan panas selama proses blansing dapat mengakibatkan terjadinya hidrolisa pati menjadi molekulmolekul gula yang lebih sederhana (Ayu dan Yuwono, 2014).

\section{KESIMPULAN}

Perlakuan blansing dapat mencegah terjadinya reaksi pencoklatan enzimatis dibandingkan perendaman dengan daging buah asam sitrat pada tepung pandan tikar yang dihasilkan; dengan nilai rendemen $(16,21 \%)$, tingkat kecerahan/nilai L (76,29), tingkat kemerahan/nilai a $(2,41)$, tingkat kekuningan/nilai b $(25,82)$, suhu gelatinisasi $\left(92,33{ }^{\circ} \mathrm{C}\right)$, kelarutan dalam air $(53,43 \%)$; serta mengandung air $(10,08 \% \mathrm{bb})$, abu $(10,00 \%$ bk), protein $(5,73 \% \mathrm{bk})$, lemak $(2,24 \% \mathrm{bk})$, karbohidrat $(82,03 \%$ bk), serat kasar $(24,42 \%$ bk) dan total gula (26,00\% bk).

\section{UCAPAN TERIMA KASIH}

Terima kasih kepada Kementerian Riset dan Teknologi-Pendidikan Tinggi melalui Direktorat Riset dan Pengabdian Masyarakat (DRPM) Direktorat Jenderal Penguatan Riset dan Pengembangan atas dana penelitian Strategis Nasional tahun 2018, sesuai dengan Surat Perjanjian Pelaksanaan Program Penelitian nomor: 080/SP2H/LT/DRPM/2018.

\section{DAFTAR PUSTAKA}

AACC (American Association of Cereal Chemist). (1983). Approved Methods of the AACC, St. Paul, USA: American Association of Cereal Chemist.

Antares, A., Wartini, M. N., and Wrasiati, L. P. (2017). Karakteristik Kapsul Ekstrak Pewarna Buah Pandan (Pandanus tectorius) menggunakan penyalut maltodekstrin dan karaginan. Jurnal Ilmiah Teknologi Pertanian Agrotechnology, 2 (2), pp. 220-226.

AOAC (Association of Official Agricultural Chemist). (2005). Official Methods of Analysis of The Association of Official Agricultural Chemist. AOAC, Inc., Washington.

Apriyantono, A., Fardiaz, D., Puspitasari, N. L., Sedarnawati dan Budiyanto, S. (1989). Petunjuk Laboratorium Analisis Pangan. Departemen Pendidikan dan Kebudayaan Direktorat Jendral Pendidikan Tinggi Pusat antar Universitas Pangan dan Gizi Institut Pertanian Bogor. Bogor.

Ayu, D. C. dan Yuwono, S.S. (2014). Pengaruh suhu blansing dan lama perendaman terhadap sifat fisik kimia tepung kimpul (Xanthosoma sagittifolium). Jurnal Pangan dan Agroindustri, 2 (2), pp. 110-120.

Inggrid, M., Lokasurya, D. S., Santoso, H., dan Hartanto Y. (2018). Pengaruh Penambahan Zat Anti-browning Alami pada Kentang. Prosiding Seminar Nasional Teknik Kimia "Kejuangan", Pengembangan Teknologi Kimia untuk Pengolahan Sumber Daya Alam Indonesia. Yogyakarta, 12 April 2018. B1-1 - B1-7.

Kusumawati, D., Amanto, B. S. dan Muhammad, D. R. A. (2012). Pengaruh perlakuan pendahuluan dan suhu pengeringan terhadap sifat fisik, kimia dan sensori tepung biji nangka (Artocarpus heterophyllus). Jurnal Teknologi Pangan, 1 (1), pp. 41-48.

Maker, D., Sarungallo, Z. L., Santoso, B., Latumahina, R.M.M., Susanti, C,M,E., Sinaga, N. I., Irbayanti, D. N. (2018). Sifat Fisik, Kandungan Vitamin C dan Total Padatan Buah Pandan Tikar (Pandanus tectorius P.). Agritechnology, 1(1), pp. 1-11. 
Mardiah, E. (2011. Mekanisme Inhibisi Enzim Polifenol Oksidase pada Sari Buah Markisa dengan Sistein dan Asam Askorbat. Jurnal Riset Kimia, 4 (2), pp. $32-37$.

Nuraini, (2011). Aplikasi Milet (Pennisetum Spp) Merah dan Millet Kuning Sebagai Subtitusi Terigu dalam Pembuatan Roti Tawar: Evaluasi Sifat Sensori dan Fisikokimia. Skripsi, Fakultas Pertanian, Universitas Sebelas Maret, Surakarta.

Pardede, M. C., Julianti, E. dan Ridwansyah. (2017). Pengaruh Suhu Blansing Dan Suhu Pengeringan Terhadap Mutu Fisik Tepung Ubi Jalar Ungu (Ipomea batatas L). Program Studi Ilmu dan Teknologi Pangan Fakultas Pertanian. Univ. Sumatra Utara. Medan.

Prabasini, H., Ishartani, D, dan Rahadian, D. (2013). Kajian sifat kimia dan fisik tepung labu kuning (Cucurbita moschata) dengan perlakuan blansing dan perendaman dalam natrium metabisulfit (Na2S2O3). Jurnal Teknosains Pangan, 2 (2), pp. 93-102.

Oktavianti, V. C. dan Putri, W. D. R. 2015. Pengaruh modifikasi fisik annealing terhadap mutu tepung ubi jalar ungu varietas ayamurasaki. Jurnal Pangan dan Agroindustri. 3 (2) : 551-559.

Raunsai, K. E. dan Elewyan, E. (2018). Potensi dan Pemanfaatan Pandanus tectorius Parkinson Sebagai Busana Tradisional di Kabupaten Nabire Provinsi Papua, 1(1), pp. 42-49.
Sarungallo, Z.L., Susanti, C.M.E., Sinaga, N.I., Irbayanti, D.N., dan Latumahina, R.M.M. (2018). Kandungan Gizi Buah Pandan Laut (Pandanus tectorius Park.) pada Tiga Tingkat Kematangan. Jurnal Aplikasi Teknologi Pangan, 7 (1), pp. 21-26. https://doi.org/10.17728/jatp.2577.

Sathe S.K, and D.K Salunkhe. (1981). Isolation, partial characterization and modification of the great northern bean (Phaseolus vulgaris L.). Journal of Food Science, 46 (1), pp. 617-621.

Sudarmadji, S., Haryono, B. dan Suhardi. (1997). Prosedur Analisis Bahan Makanan dan Pertanian. Liberty. Yogyakarta.

Suprapto. (2004). Pengaruh Lama Blanching Terhadap Kualitas Stik Ubijalar (Ipoema Batatas L.) dari Tiga Varietas. Balai Penelitian Tanaman Kacang-kacangan dan Umbi-umbian. Malang.

Vahirua-Lechat, Menut, C., Roig, B., Bessiere, J.M. and Lamaty, G. (1996). Isoprene Related Esters, Significant Components Of Pandanus Tectorius. Institut Malardd, Tahiti, Polyndsie franqaise; Universit6 de Montpellier II, 34095 Montpellier Cedex 5, France. Winarno, F.G. (2008). Kimia Pangan dan Gizi. PT Gramedia Pustaka, Jakarta. 